Dorota Werbińska

Akademia Pomorska w Słupsku

\title{
BIOGRAFIA ZAWODOWA JAKO ŹRÓDŁO WIEDZY - AUTOBIOGRAFICZNE REFLEKSJE EMERYTOWANYCH NAUCZYCIELEK JĘZYKA OBCEGO ${ }^{1}$
}

\author{
Professional biography as a source of knowledge: \\ Autobiographic reflections of retired language teachers
}

This article reports a qualitative research project focused on examining the professional biographies of four post-service Polish teachers of foreign languages. The main objective was to find out what experiences in their professional biographies the participants perceived as the most critical, and to see if those memories were roughly similar in the participants' accounts. Following Karol Wojtyła's (1994) anthropological views connected with a person's structure and their dynamism, the study discusses the subjects' experiences relating to teacher reactivity, emotivity and agency against the socio-political background of Poland in the period before and after political transformation.

Keywords: biographies, reflection, foreign language teachers, retired teachers, reactivity-emotivity-agency, Poland

Słowa kluczowe: biografie, refleksja, nauczyciele języka obcego, nauczyciele emerytowani, reaktywność-emotywność-sprawczość, Polska

1 Autorka składa serdeczne podziękowania uczestniczkom badania za wyrażenie zgody na udział w nim. 


\section{Wstęp}

Wykorzystanie metody biograficznej na gruncie badań z zakresu akwizycji języka od kilku lat cieszy się dużym zainteresowaniem, zwłaszcza wśród badaczy stosujących metody jakościowe. Jest tak, gdyż biografie są żywym przykładem historii człowieka, opowieściami własnego życia wyzwalającymi refleksję. Choć niewątpliwie analizy biograficzne czynnych nauczycieli pozwalają na lepsze poznanie, opisanie czy interpretację różnorodnych zjawisk glottodydaktycznych, istnieje grupa pedagogów stanowiąca rzadki obiekt badań dotyczących procesu nauczania i uczenia się języków obcych - emerytowani nauczyciele języków obcych (JO), których biografie językowe poddane refleksji, mogłyby przyczynić się do wzbogacenia naszej wiedzy glottodydaktycznej, czy poszerzenia horyzontu myślowego.

\section{Dlaczego nauczyciele emerytowani?}

Istnieją przesłanki, aby zajmować się doświadczeniem zawodowym byłych nauczycieli JO z przynajmniej kilku powodów. Po pierwsze, nauczyciele, którzy formalnie mogą już zaprzestać pracy zawodowej, mają w stosunku do niej poczucie dystansu i „przeszli z jednej wspólnoty dyskursu do innej” (Wejland, 2011: 16). Dzięki temu mogą dokonać bardziej wnikliwej refleksji nad przebytą drogą zawodową, a przez to służyć lepszą radą młodszym nauczycielom. W tym znaczeniu refleksja biograficzna przyjmuje dwa wymiary: retrospektywny, gdyż dotyczy wydarzeń minionych, jak również prospektywny, gdyż skierowana do innych, jest nastawiona na przyszłość słuchających. Po drugie, sposób konceptualizacji rzeczywistości zawsze zależy od kontekstu, czyli miejsca, w którym żyjemy i z którego patrzymy. Dlatego studiowanie biografii emerytowanych nauczycieli jest właściwie studiowaniem ich socjobiografii, umożliwiających poznanie kulturowych wyznaczników czasów, w których przyszło im żyć poprzez pryzmat konkretnej jednostki. Malewski (2010: 156) twierdzi, iż „narracja jest kwestią społeczną (...) nawet wówczas, gdy dotyczy doświadczeń osobistych". Nowak-Łojewska (2011: 213) z kolei uważa, że o „charakterze wiedzy nie przesądza to, co jest jej przedmiotem, ale społeczne okoliczności wytwarzania i funkcjonowania tej wiedzy". Stąd to, co uznajemy za biograficzne fakty, jest odbiciem dyskursów kształtujących życie konkretnych nauczycieli, odzwierciedleniem makrostruktur społecznych, które biograficznie „odcisnęły się” na nich (Malewski, 2010: 161). Po trzecie, żyjemy w kulturze narracji, biografizmu i autobiografizmu, określanej czasami jako „narracyjny zwrot” (narrative turn) (Pavlenko, 2007: 164). Znamy biografie i autobiografie artystów i naukowców, zaś w dyskursie glottodydaktycznym 
pojawiają się biografie wybitnych uczniów (Biedroń, 2012), wyróżniających się nauczycieli praktyków (Werbińska, 2004), jednym słowem, tych, którzy odnieśli sukces. Raczej nieznane są opracowania na temat trudu pedagogicznego zwykłych nauczycieli JO, czy na temat ich wiedzy biograficznej konstytuowanej lokalnie (Ligus, 2009: 13). W biografiach podejmowane są przeważnie wydarzenia niecodzienne, zaś ci, których życie przebiega zwyczajnie między pracą a domem nie wiedzą, jak opowiadać o sobie (Lalak, 2010: 124). Po czwarte, warto zaznaczyć, że faza życia na emeryturze straciła swój „statyczny i spoczynkowy charakter" (ibidem: 142), a klasyczny trzyfazowy podział życia: przygotowanie do roli człowieka dorosłego, dorosłość, emerytura i stan spoczynku, przestał być wystarczającym instrumentem opisu ludzkiego życia (Lalak, 2010). Podejmuje się badania na temat estetyzacji starości (Dubas, 2011: 203), bada uczniów JO po 50 roku życia (Jaroszewska, 2013), prawdopodobnie wychodząc z przekonania, że dojrzały wiek stanowi wartość samą w sobie. Brak oddania głosu emerytowanym nauczycielom języków obcych może prowadzić, z jednej strony, do wykluczenia tej grupy z opracowań badawczych, zaś z drugiej strony do niewykorzystania jej potencjału, jako cennego źródła rozszerzenia wiedzy o nauczycielu, jego środowisku czy społeczno-kulturowych następstwach.

Po piąte, w badaniach pedeutologicznych, dzięki zastosowaniu metody jakościowej, odchodzi się od kompetencyjnego modelu myślenia o nauczycielu, oderwanego od dzisiejszych potrzeb i rzeczywistości. Współczesne paradygmaty inspirują nie do badania skuteczności pracy nauczyciela, idealnych cech czy przypisanych ról społecznych (Kwiatkowska, 2004), ale do zgłębiania jego osobistego sposobu rozumienia świata pod wpływem społecznie nagromadzonych doświadczeń. Dlatego badanie biografii nauczycieli umożliwia dotarcie do nauczycielskiego procesu konstruowania, rekonstruowania czy dekonstruowania indywidualnych doświadczeń. W końcu, refleksje na temat biografii zawodowych innych nauczycieli powodują pojawienie się refleksji u odbiorcy. Jest tak, gdyż lubimy porównywać się z innymi, a niekiedy w wypowiedziach innych, znajdujemy drogowskazy dla własnego działania. Słuchanie refleksji tych, którzy mają drogę zawodową już za sobą, może dlatego stanowić okazję do własnych samoocen i syntez swojego życia, czy zrozumienia kluczowych momentów własnego rozwoju zawodowego.

\section{Badanie}

Przedmiotem projektu uczyniono dwa problemy badawcze:

- Co badani emerytowani nauczyciele różnych języków obcych uznają za ważne doświadczenia, jaki nadają im sens i jak je interpretują? 
- Jakie podobieństwa i różnice można wyodrębnić w biografiach badanych nauczycieli ze względu na nauczany język obcy?

\subsection{Dobór uczestników i organizacja badania}

Uczestniczkami badania były 4 emerytowane nauczycielki: 2 języka niemieckiego (Inga i Marlena), 1 języka rosyjskiego (Lena) i 1 języka angielskiego (Anna) $)^{2}$. Dobór próby badawczej opierał się na trzech kryteriach: pobierania świadczeń emerytalnych, długoletniej pracy w szkole w charakterze nauczyciela JO oraz zgody na udział w badaniu. Wywiady narracyjne przeprowadzono w okresie od maja do lipca 2013 roku. Wszystkie respondentki wyraziły zgodę na nagrywanie swoich refleksji. Dodatkowo badaczka sporządzała notatki.

\subsection{Praca nad materiałem}

Choć istnieją różne propozycje analiz biografii autorkę zainspirowało podejście antropologiczne, powstałe na gruncie poglądów Wojtyły (1994; 1999; Łatacz, 2011), które pozwalają spojrzeć na biografię człowieka od strony antropologii, wyodrębniając strukturę i dynamikę osoby. W skład pierwszej wchodzą trzy warstwy: somatyczna, psychiczna i osobowa ${ }^{3}$, a każdej z nich odpowiadają następujące dynamizmy: warstwie somatycznej - reaktywność, warstwie psychicznej - emotywność, a warstwie osobowej - sprawczość. Ponieważ warstwy składające się na strukturę danej osoby są bardziej ogólne niż dynamizmy, przez co mniej nadają się do czerpania konkretnej wiedzy z ludzkiej biografii, za „klucze” do analiz biografii nauczycielek przyjęto dynamizmy, które stanowią o podstawowych właściwościach życia badanych osób.

Reaktywność, ściśle powiązana z żywotnością ciała ludzkiego, oznaczała w badaniu reakcje i zachowania nauczycielek, które nie stanowiły ich preferencji, czy świadomego działania z użyciem woli, a były swoistą koniecznością, mającą na celu przetrwanie człowieka. Takie reaktywne, wegetatywne i poniekąd pozawolicjonalne postępowanie konkretnej osoby ma raczej zewnętrzny charakter ${ }^{4}$. Emotywność oznaczała w badaniu odczucia badanych w odniesieniu do wartości, a ściślej tego, co czuły w różnych sytuacjach obcowania z języ-

\footnotetext{
${ }^{2}$ Imiona uczestniczek zostały zmienione.

${ }^{3}$ Wojtyła mówi o czterech warstwach, gdyż oprócz trzech wymienionych, jest również czwarta warstwa - „nad-natury”, której odpowiadają takie dynamizmy jak wiara, nadzieja i miłość. Ma ona konotacje teologiczne i mistyczne, nieistotne dla analizy zagadnienia w tym opracowaniu.

${ }^{4}$ Reaktywność człowieka stanowiła podstawę do stworzenia koncepcji temperamentu.
} 
Biografia zawodowa jako źródło wiedzy - autobiograficzne refleksje...

kiem. Ten dynamizm człowieka ma charakter spontaniczny, wskazujący na to, że coś dzieje się w jego psychice i odnosi się, z jego punktu widzenia, do prawdziwości. Przekonanie osoby ulegającej emocji o tym, że ma w danej chwili rację i mówi prawdę jest też ukazaniem jej wrażliwości na pewne wartości, jak również wyrazem autentyczności w ich przeżywaniu. Sprawczość, trzeci z dynamizmów psychiki człowieka, wskazuje na świadomość, podmiotowość, akt woli. Osoba w tej warstwie jest sprawcą swoich czynów, samopostanowień, wyborów, odczuć, że to „ona sama działa”, a nie, że „coś się z nią dzieje”.

\section{Wyniki badania i interpretacja}

Narracje badanych nauczycielek posłużyły do zrekonstruowania przypisywanych znaczeń w odniesieniu do dynamizmów reakcyjności, emotywności i sprawczości. Przy każdej z tych porządkujących koncepcji przywołano przykładowe fragmenty narracji, zakładając, że wypowiedzi potwierdzą występowanie dostrzeżonych zjawisk, a tym samym uwiarygodnią wyodrębnienie takich, a nie innych koncepcji znaczeń.

\subsection{Reaktywność}

W kategorii reaktywności wyodrębniono dwie podkategorie ${ }^{5}$ : wybór kierunku studiów językowych, który decydująco wpływa na dalsze losy zawodowe osoby oraz wybór zawodu nauczyciela JO. Choć można polemizować z wyróżnieniem podkategorii „wybór zawodu” jako dynamizmu reaktywnego, argumentując, że decyzje o kierunkach studiów są autonomiczne i podejmowane samodzielnie, wypowiedzi narratorek dobitnie ukazują, że nie miało to miejsca $w$ ich przypadku. Obie germanistki pochodziły $z$ autochtonicznych rodzin pomorskich, języka niemieckiego używały w domu i przy spotkaniach rodzinnych, a dodatkowo jedna z nich co roku wyjeżdżała na wakacje do Austrii. W praktyce oznaczało to, że obie płynnie posługiwały się językiem niemieckim i być może rozpoczęcie innego kierunku studiów niż filologia germańska byłoby ich autonomiczną decyzją podjętą wbrew oczekiwaniom nauczycieli czy znajomych. Nie sugeruje się tutaj wyboru najłatwiejszego, ale nie można uznać, iż były to studia bardzo trudne dla tych konkretnych osób. Pozostałe nauczycielki również zastanawiały się nad innymi kierunkami studiów, sugerując się systemem subiektywnych wartości czy łatwością przyjęcia na studia. Ze wszystkich narracji wynika, że ostateczne decyzje podejmowali inni, najczęściej nauczyciele lub koleżanki. Można zatem pokusić się

\footnotetext{
${ }^{5}$ Ze względu na ograniczoną objętość artykułu, pominięto podkategorię przepracowania.
} 
o tezę, że decyzje o rozpoczęciu studiów filologicznych były przypadkowe, odbiegające od lansowanej ostatnio motywacji idealnej (Ideal L2 Self motivation), (Dörnyei, 2009), choć Inga i Lena już wtedy wykazywały zainteresowanie literaturą i kulturą obszarów językowych, których języki miały studiować, przekładające się na motywację integrującą (Gardner i Lambert, 1972).

Wybór zawodu nauczyciela był także w pewnym stopniu przypadkowy, gdyż żadna z badanych nie wyobrażała siebie, ani przed studiami, ani w trakcie studiów, jako nauczycielki. O wyborze profesji zdecydowały rozwiązania systemowe, takie jak nakazy pracy, odpracowanie stypendium czy uzyskanie mieszkania. Jest to ciekawe, gdyż tak jak w przypadku wyboru studiów, nie było tu miejsca na marzenia o pracy nauczyciela czy idealistyczne wizje własnego wkładu w rozwój edukacji językowej innych. Inga nawet podaje prawdopodobną przyczynę, kiedy twierdzi:

Chyba zraziła mnie do tego pewna dziewczynka, którą kazano mi uczyć czytać. Rodzice jej przyjęli mnie kiedyś na całe wakacje do Gdyni, to byli znajomi mamy, a ja miałam ich córkę uczyć przez całe wakacje czytania. Byłam w IV czy V klasie, miałam z nią czytać książeczki. Tak mnie to zraziło. Jak mi kazano $z$ rodzeństwem odrabiać lekcje, było to dla mnie najgorsze zajęcie ${ }^{6}$.

Choć z perspektywy czasu wszystkie nauczycielki oceniają wybór zawodu pozytywnie, w momencie decyzji o rozpoczęciu pracy nie były tą pracą zachwycone. Przyjęły ją jako zrządzenie losu, „robotę do wykonania”, zaś pozytywne emocje nastąpiły później, w trakcie wykonywania pracy.

\subsection{Emotywność}

Drugi „klucz” do tożsamości człowieka, emotywność, obejmuje całą gamę ludzkich odczuć, takich jak wzruszenia, uczucia, namiętności, pasje wpływające na określone zachowania. Już etymologicznie emotywność wskazuje na jakieś poruszenie od wewnątrz (łac. ex-movere). W przeciwieństwie do reaktywności, „dynamizm ciała zostaje przekroczony", a podstawową formą stają się odczucia krystalizujące przeżywanie przez człowieka wartości (Łatacz, 2011: 97-98). Jakie odczucia wystąpiły u nauczycielek w ich biograficznych narracjach? Analiza materiału empirycznego umożliwia podział doznań na te, które uważamy za pozytywne, jak również te, które nie dostarczają przyjemnych wspomnień w momencie refleksji .

\footnotetext{
${ }^{6}$ Wszystkie przypisy są oryginalne, bez ingerencji stylistycznej.

${ }^{7}$ Ze względu na ograniczoną objętość artykułu, pominięto kategorię rozczarowania oraz kategorię żalu.
} 
Poczucie satysfakcji

Kwestią wartą odnotowania jest poczucie satysfakcji zawodowej cechujące wszystkie badane osoby. Dla Ingi jest to „najpiękniejszy zawód na świecie” gwarantujący wieloletnie kontakty z człowiekiem, "morze kontaktów międzyludzkich”, zwłaszcza, jak to określiła, „dla 'stadnego' człowieka”. Podobnie o zawodzie nauczycielskim wyrażają się Marlena i Anna, choć ta pierwsza dodaje, że dotyczy to tylko najważniejszych relacji, tych pomiędzy nauczycielem a uczniami, gdyż relacje z współpracownikami mogą być różne. Poczucie spełnienia zawodowego ze względu na dobre relacje z uczniami może dotyczyć każdego przedmiotu. Dlatego istotne jest dla niniejszej analizy, co takiego pozytywnego znajduje się w zawodzie nauczyciela JO, dzięki czemu można czerpać satysfakcję. Według Ingi nauczyciel JO ma szczególne zadanie do spełnienia, gdyż musi rozwijać świadomość różnorodności, tolerancję na nią, nawiązywać do globalności świata. Są to bardzo ważne słowa, nawiązujące do współczesnych ról nauczyciela JO, któremu wyznacza się funkcję pośrednika kulturowego (Zawadzka, 2004: 185-214), promotora zgody i pokoju między narodami, rzecznika globalnego społeczeństwa obywatelskiego (Birch, 2009). Natomiast Lena odwołuje się do swoich osobistych doświadczeń nauczyciela języka rosyjskiego, twierdząc, że gdyby uczyła innego przedmiotu albo w innych czasach, nie miałaby poczucia takiej satysfakcji.

Czuję satysfakcję z tego, że uczyłam rosyjskiego. Rosyjski zmusił mnie do dużego rozwoju, do poszukiwania czegoś motywującego, gdy motywacja uczniów zupełnie odeszła, wszystko stało się nieaktualne, wszystkie „ogonioki” warte funta kłaków, gdyż tym językiem już nikt nie mówił. Rosjanie zostali wyzwoleni z tego pustosłowia i nagle ja przestałam słyszeć, bo nie miałam już prasy. Wtedy to była czarna dziura -gwałtowne poszukiwanie motywacji. Byłam pierwszym egzaminatorem ( $\mathrm{nr} 2$ jako egzaminator maturalny), jedną z pierwszych edukatorek uczenia rosyjskiego metodą komunikacyjną. Germaniści przygotowali pierwszą grupę rusycystów do pracy dalej, ja się tam znalazłam w tych grupach prekursorskich. Gdybym była starsza, nie miałabym tego. Coraz bardziej utwierdzałam się, że chcę robić to, co robię.

Uzyskane wypowiedzi pokazują, że wykonywanie pracy nauczyciela przynosi satysfakcję rozmówczyniom. Być może jest to także podyktowane wysokim przekonaniem o własnej skuteczności, związanym z wiarą, że zdołają sprostać wymaganiom danej sytuacji. Anna przypomina zdarzenie, gdy została poproszona przez profesora uczelni o udzielanie lekcji z języka angielskiego, kiedy jeszcze była studentką. 
Ojciec tej uczennicy powiedział mi, jakie były kulisy mojego zatrudnienia. Jego znajomy, mój profesor, dał mu 2 propozycje: koleżankę z roku, która kończyła szkołę w Anglii i mnie z takim komentarzem, że tamta bardzo dobrze zna angielski, a ja nie znam dobrze, ale potrafię nauczyć.

\section{Podejście do nauczania kultury}

Interesujące jest podejście badanych do nauczania kultury kraju, którego języka nauczają. Można wyróżnić w nim trzy postawy: fascynacji, poczucia obowiązku wynikającego z nauczania przedmiotu, jakim jest język obcy, jak również pominięcia kwestii nauczania kultury w ogóle.

Zafascynowana kulturą germańską jest Inga, co wynikało z jej wczesnego obycia z kulturą austriacką, a także dzięki profesorowi literatury. Nauczycielka mówi:

Byłam zafascynowana profesorem C., zajęciami, literaturą, którą pokazywał nam od innej strony. Nikt więcej nigdy nie mówił na temat Polenliteratur, która powstała na terenie Niemiec w XIX wieku po powstaniach, która była przychylna Polakom. On nam pokazywał, że te relacje między Polską a Niemcami były też inne, że potrafili dowartościować polski wkład w powstania, żeby się usamodzielnić, ich walkę z Prusami itd.

Zainteresowanie kulturowością przeniosło się także na dydaktykę Ingi, a w konsekwencji na zainteresowania jej uczniów:

Przychodząc (...) na pierwszą lekcję, opowiadałam o innych Niemcach niż on znali. Mówiłam o Niemcach, którzy budowali obozy koncentracyjne, ale obok był Weimar jako kolebka europejskiego humanizmu. Przywiesiłam portrety Goethego, Schillera, prowadziłam jakieś teatrzyki ze scenkami w języku niemieckim, jakieś konkursy, szukaliśmy poniemieckich materiałów w mieście, przywoziłam albumy z Austrii i pokazywałam uczniom, co odbiło się na ich zainteresowaniu językiem.

Podobną fascynację kulturą i literaturą rosyjską odczuwała Lena. W tamtym czasie, w stanowisko nauczyciela języka rosyjskiego wpisana była rola propagatora kultury radzieckiej, wspomagana działaniami Instytutu Puszkina i Łomonosowa $z$ intencją przygotowania młodzieży do konsumpcji kultury radzieckiej w oryginale. Lena nie narzeka na to, gdyż propagowanie kultury, wystawianie "Ożenku” Gogola w oryginalnej wersji w licealnej auli, obcowanie z literaturą w każdej formie dostarczało jej przyjemności. 
Biografia zawodowa jako źródło wiedzy - autobiograficzne refleksje...

Marlena postrzega znajomość i kontakt z niemiecką kulturą jako integralny element pracy nauczyciela JO. Dla niej samej literatura i kultura mają ogromne znaczenie.

Jak tylko mam czas, oglądam dzienniki, cały czas dużo czytam. U mnie w domu cały czas leci program niemiecki, najczęściej programy publicystyczne. Jestem absolutnie na bieżąco, ponieważ uważam, że nie można uczyć języka w oderwaniu od kultury tego kraju. Jeśli nie orientuję się w tej kulturze, w tej rzeczywistości, o czym mam mówić po niemiecku? O polskiej rzeczywistości?

Podejście germanistek i rusycystki wyraźnie kontrastuje z podejściem do nauczania kultury anglistki Anny. W jej wypowiedzi brakuje identyfikacji z kulturą krajów nauczanego języka, a nawet występuje „odrzucenie” odczuć. Anna opowiada:

Identyfikuję się z zewnątrz. Pewna osoba powiedziała mi o naszym pierwszym spotkaniu: „Taka Angielka przyszła, jeszcze w spódnicy w kratę.” Ja jestem i byłam bardziej nauczycielem języka angielskiego niż anglistką. Traktuję angielski jako Lingua Franca. Literatura, kultura - mnie to nie pociąga. I poza tym, nie czuję i nie czułam potrzeby uczenia o kraju, tylko uczenia jako dawania narzędzia porozumiewania się w tej sytuacji, w jakiej jest angielski obecnie. Cała metodyka idzie w tym kierunku, problemy globalne, międzynarodowe podręczniki, rozmaite akcenty. To mi odpowiada. Jedna z uczennic prosiła mnie, abym do konkursu ją przygotowała z wiedzy o Anglii i Stanach. Myślałam sobie, Boże, jak przygotować? Niech sobie coś poczyta o tym.

Niewątpliwie każdy nauczyciel ma swoje przekonania kierujące jego pracą. Chociaż kwestie interkulturowości stanowią ważny aspekt dydaktyki JO, opinie nauczycieli, podobne do tych, które prezentuje Anna nie należą do rzadkości. Być może jest to związane ze specyfiką nauczanego języka. Angielski jako język globalny wyzwala inne oczekiwania, niż języki o mniejszym zasięgu. Nauczanie aspektów kulturowych jest częstym argumentem na rzecz wzbudzania motywacji uczniów do uczenia się języka. W czasach, kiedy nauka języka angielskiego jest uważana za normę, a język za narzędzie potrzebne do funkcjonowania we współczesnym świecie, można nauczanie języka sprowadzić do samego operowania językiem. Może się także zdarzyć, że wiedza kulturowa prezentowana na lekcjach języka jest dla ucznia kolejnym polem do porażki. W konsekwencji, następuje blokada w rozwoju innych obszarów językowych, skutkująca podejściem typu „nie wiem, nie czuję, nie rozumiem”. Z drugiej strony, w swojej wypowiedzi Anna odnosi się do aspektów globalnych, akcentów międzynarodowych, zatem kultura przez małe „k” bywa obecna na 
jej zajęciach. Może to także wynikać z jej odmiennej koncepcji nauczania kultury, rozumianej jako nauczanie wyłącznie kultury wysokiej, bez odwołania do innych znaczeń nauczania kultury - interkulturowości, wielokulturowości czy transkulturowości (Risager, 1998: 243-252).

\section{Wstyd}

Wstyd nie jest doznaniem, którym ludzie lubią się dzielić. Opowiadania o wstydliwych sytuacjach mogą nawet po latach powodować zażenowanie i z tego względu narratorzy biografii mogą intencjonalnie ich unikać. Pojawienie się wstydu w narracjach miało miejsce w refleksjach trzech nauczycielek i dlatego nie można pominąć tego doznania w analizie materiału. Chyba najbardziej interesującym przeżywaniem wstydu były wspomnienia Leny, doświadczającej upokorzenia ze względu na odbiór języka rosyjskiego na początku lat $90 .^{8}$

Był czas, kiedy rosyjski był upokarzany, lekceważony jako nie wiadomo co, kojarzony z Dworcem Centralnym, warszawskim stadionem. Imponowali Anglicy, Francuzi swoją kulturą, przede wszystkim sytuacją materialną (...) wstyd się było przyznać, że uczy się rosyjskiego.

Lena wspomina niski status rosyjskiego związany ze złą sytuacją ekonomiczną krajów Federacji Rosyjskiej, porównywanie „opłacalności” uczenia się rosyjskiego z możliwościami, jakie dawała nauka języków zachodnich. Choć motywacja do nauki języka jest kategorią psychologiczną, uczenie się języków zachodnich jako „inwestycja w siebie” (Norton, 2013), jest konstruktem socjologicznym, którego natężenie w Polsce przypadło na początek lat 90. Nauka niektórych języków nie jest uważana za inwestycję w siebie, zaś nauka innych umożliwia dostęp do większych zasobów materialnych i symbolicznych.

Jednak niski status języka rosyjskiego nie był powodowany tylko złą sytuacją ekonomiczną czy skojarzeniami politycznymi. Lena, jak twierdzi, uczyła "na stopnie”, cały czas „wytykając” uczniom ich błędy. Dodaje, że sama była uczona w ten sposób, gdyż metodyka to zakładała. Dziś, jak przyznaje, wstydzi się, że tak uczniów traktowała, że z niektórymi popadała w konflikt, że oceniała nie tylko postępy językowe, lecz także pamięciowe opanowanie tekstu. Dopiero po zetknięciu się z dydaktyką zachodnią zrozumiała, że można stawiać osobne oceny za różne aspekty języka, a dzięki temu wytłumaczyć

\footnotetext{
8 Badane germanistki wstydzą się za wielu współczesnych nauczycieli, zarówno młodszych, jak i starszych wiekiem, którzy lubią pokazywać swoją przewagę i wyższość względem uczniów i ich rodziców. Ze względu na ograniczoną objętość artykułu, doznania wstydu germanistek zostały pominięte.
} 
Biografia zawodowa jako źródło wiedzy - autobiograficzne refleksje...

uczniowi, co mu się udaje, a co jeszcze nie. Poniższe słowa dobrze ilustrują zmianę, jaka zaszła w świadomości nauczycielki:

W kontaktach z Rosjanami uczniowie bali się usta otworzyć, bali się, że mówią coś źle. Nagradzani byli tylko ci, którzy mówili tak, aby nie byli odróżnieni od tubylców. To był koszmar, a teraz wstyd. Jestem taka szczęśliwa, że z tego wyszłam.

\subsection{Sprawczość}

Trzecim „kluczem” do badania biografii emerytowanych nauczycielek była sprawczość, dynamizm odnoszący się do warstwy osobowej, wpływający na realizację samopostanowień, a dzięki temu samospełnienia. Efektem sprawczości jest transcendencja, czyli przerastanie samego siebie, polegająca na tym, że „'ja' staje się przedmiotem dla siebie samego - przedmiotem woli jako władzy stanowiącego podmiotu" (Łatacz, 2011: 101). W rezultacie stare schematy okazują się nieprzydatne w zmieniającej się rzeczywistości, a wyzwoleniem okazuje się samorefleksja, prowadząca do odkrywania nowych perspektyw i znaczeń, samodzielnego wytworzenia wiedzy, a co za tym idzie, potężnej zmiany rozwojowej. Próbując sprowadzić przykłady sprawczości narratorek do „wspólnego mianownika”, okazuje się, że wywodzą się one z potrzeby zmiany, podyktowanej pragnieniem uatrakcyjnienia lekcji JO, potrzebą aktywności i ambicją, sprowadzającej się następnie do wypracowania własnej koncepcji dydaktycznej. Przyjrzyjmy się zatem temu, co badane samodzielnie zdecydowały i realizowały w poczuciu, że postępują słusznie.

Borykając się z problemem niskiej motywacji uczniów, Inga postawiła na kulturę wysoką krajów niemieckojęzycznych. Później, gdy zainteresowanie wzrosło, jej lekcje oznaczały skuteczne przygotowywanie do egzaminu maturalnego i olimpiad językowych. Gromadziła w tym celu testy, przepisywała je odręcznie przez kalkę, kolekcjonowała stare podręczniki do niemieckiego, które dostarczały nieznanych wcześniej tekstów do rozwijania sprawności czytania, pożyczała swoje książki. To wystarczyło, aby zawsze mieć chętnych uczniów do pobierania u niej nauki. Marlenie, z kolei, bliższe były koncepcje wychowawcze od dydaktycznych. Jej motto stanowiło bycie sprawiedliwym, docenianie wszystkiego, nagradzanie uczniów, zwłaszcza tych mniej zdolnych językowo, za drobne sukcesy. W rozmowie stwierdziła, że jej strategia sprawdza się do tego stopnia, iż nigdy żaden mniej zaawansowany językowo uczeń nie powiedział nic krytycznego pod jej adresem. Istotne jest, że Marlena dostrzega ucznia przeciętnego. W dzisiejszych czasach, kiedy awans nauczyciela zależy od liczby wypromowanych olim- 
pijczyków ${ }^{9}$, a zdolności ucznia podkreśla się na każdym kroku, troska o tak zwanych „uczniów środka” ${ }^{10}$, których jest najwięcej, wydaje się optymalną. Warto przypomnieć, że jedną z cech dobrego nauczyciela jest umiejętność skutecznej pracy z uczniem słabszym, gdyż zdolny uczeń, wspierany i monitorowany przez nauczyciela, zwykle potrafi uczyć się sam.

Dydaktyka języka rosyjskiego Leny podlegała szerszym wpływom kulturowo-społecznym. Jeszcze przed transformacją ustrojową, regularnie otrzymywała od znajomych Rosjan współczesną prasę i literaturę, tworząc najlepiej wyposażony gabinet języka rosyjskiego w mieście. Twierdziła, że podręcznikowe teksty o Prosi traktorzystce, pisane propagandowym językiem czy streszczenia fragmentów Tołstoja z nachyleniem prosowieckim, nie odpowiadały mentalności ucznia szkoły średniej. Świadomie przekazywała im swoją pasję i swoje emocje, co wystarczało, aby odnosić sukcesy dydaktyczne. Kiedy w latach 90. nie miała tekstów, gdyż do języka Tołstoja, ze względu na niski poziom uczniów, wrócić nie było można, wraz z innymi rusycystkami, pobierała lekcje od zachodnich dydaktyków, stworzyła grupę ogólnopolską, a nową wiedzę przekuwała w nowe standardy i podręczniki. Uznała, że jako rusycystka, ma najwięcej do zrobienia na polu metodycznym z powodu, jak stwierdziła, „długoletniego zacofania dydaktycznego". Co ciekawe, Lena zawsze uważała się za praktyka, który nie ma pragnienia przekazywania swojej wiedzy innym. Jej relacje z uczniami podyktowane były pasją, wynikającą z jej osobowości, doświadczenia i kontaktów. Twierdziła, że „może podpowiedzieć, pomóc, określić możliwości, podzielić się swoją wiedzą", natomiast nigdy nie odważyłaby się nakazać komuś, jak ma się uczyć, gdyż tak bardzo jest to związane z osobowością osoby uczącej się. Wypowiedź Leny odpowiada współczesnym dyskursom glottodydaktycznym, gdyż promuje autonomię ucznia. Pomimo faktu, iż dydaktyka rosyjska była, jak uważała Lena, zapóźniona, nauczycielka potrafiła odwrócić się od obowiązujących podręczników i w przestrzeni, w której wolno jej było się poruszać, odnaleźć swój klucz do rozwijania pasji u uczniów.

Tendencje buntownicze miała też Anna. Już w szkole średniej, potrafiła wymyślić sposób na przetrwanie nudnych lekcji, ucząc się samodzielnie tego, co pragnęła wyrazić. Poniższe słowa ilustrują jej zabawy podczas lekcji:

Podręczniki wtedy były takie szare, czarno-białe, jakaś ilustracja czasami przedstawiająca rodzinę Wilsonów. Siłą rzeczy przerabiałam ten podręcznik

\footnotetext{
${ }^{9}$ Liczba olimpijczyków jest podstawowym kryterium potrzebnym do zdobycia stopnia profesora oświaty.

${ }^{10}$ Termin często stosowany przez konsultantów metodycznych ośrodków doskonalenia nauczycieli.
} 
Biografia zawodowa jako źródło wiedzy - autobiograficzne refleksje...

i siłą rzeczy zabijałam czas na lekcji, gdyż ucząc się dodatkowo w Empiku, były to dla mnie rzeczy łatwe. Razem z koleżanką, też zaawansowaną językowo, tworzyłam nowe czytanki, z nowymi historyjkami o Wilsonach. Czytając na przykład o tym, że dr Wilson jedzie na konferencję do Edynburga, w dymkach wymyślałyśmy nowe sytuacje w języku angielskim, że ma kochankę w Edynburgu, że ich córka Susan jest nastoletnią prostytutką, zaś syn Peter, pod wpływem narkotyków, dokonuje włamań. I tak przetrwałam te 4 lata z Wilsonami, niechcący się ucząc.

Na studiach zdecydowała się na zdrowotny urlop dziekański, lecz aby nie tracić kontaktu z uczelnią, wymyśliła koło naukowe, powołała trzyosobowy zarząd, utworzyła sekcje, zapraszała prelegentów do ich prowadzenia, a uwieńczeniem dwóch lat działalności koła była organizacja dwóch ogólnopolskich konferencji studenckich.

Pod koniec pracy zawodowej, Anna opracowała swoją własną metodę nauczania języka angielskiego osób dorosłych, opartą na gramatyce i procedurach, powstałą na podstawie obserwacji uczniów przez 20 lat. Jej metoda, którą stosuje na lekcjach prywatnych, polega na niezwykle uporządkowanym dostarczaniu wiedzy. W tej metodzie, zagubienie ucznia może trwać tylko przez moment, gdyż Anna wie, którą procedurę, w stosunku do jakiego ucznia, należy wprowadzić. Można powiedzieć, że decyzje i działania Anny były optymalne dla niej w sytuacjach językowych, w których się znalazła. Jako uczennica, potrafiła uczyć się rzeczy nowych na lekcjach angielskiego, pomimo nudnych i łatwych dla siebie lekcji. Jako studentka, potrafiła doprowadzić do założenia koła naukowego, dostarczającego jej samej nowych wrażeń i uznania. Jako nauczycielka, opracowała swoją metodę nauczania, opartą na gramatyce, być może bardziej odpowiadającą jej, niż jej uczniom. W narracji Anny nie istnieją problemy z mało zmotywowanymi uczniami, niskim statusem języka angielskiego, które wystąpiły u germanistek czy rusycystki. Z biografii Anny dowiadujemy się, że są nauczyciele podporządkowujący swoje działania temu, co jest najlepsze dla nich samych, choć inni również mogą skorzystać na tych wyborach.

\section{Refleksje końcowe}

Zgromadzony materiał empiryczny dotyczący analizy biografii 4 nauczycielek wyznacza szeroki teren eksploracji. Niemniej, z retrospektywnego punktu widzenia autorki, analiza materiału nie była łatwym zadaniem. Ważnym zbiorem czynników były różnice jakościowe w narracjach - indywidualne cechy narratorek, takie jak refleksyjność, pamięć autobiograficzna, skłonność do długich bądź krótkich wypowiedzi, stopień otwartości czy zaufania do badaczki. W tym 
badaniu szkieletem nadającym kształt było poszukiwanie „klucza” do nauczyciela, z wykorzystaniem koncepcji zaproponowanej przez Wojtyłę. Dzięki temu można było zidentyfikować występowanie przejawów reaktywności, emotywności i sprawczości w biografiach zawodowych narratorek w różnych fazach ich życia, uporządkować ich doświadczenia, nadać im sens. Jakie walory edukacyjne i poznawcze możemy znaleźć w doświadczeniach byłych nauczycielek? Czego możemy nauczyć się z badania ich biografii lub ich krytycznej refleksji, w odniesieniu do pytań badawczych postawionych w projekcie? Oto najważniejsze wstępne wnioski z całego projektu badawczego:

1. Wybór zawodu nauczyciela JO jest często przypadkowy, choć można go polubić i czerpać satysfakcję z wykonywania go. O radości i inspiracji może decydować pasja uczenia się języka i poznawania kultury danego kraju (przykłady germanistek i rusycystki), jak również postawa autonomiczna nauczyciela polegająca na nieustannym poszukiwaniu własnych rozwiązań dydaktycznych (przykład anglistki).

2. Nauczanie elementów kulturowych na lekcji JO może zależeć od statusu nauczanego języka. W przypadku języków mniej popularnych, nauczanie o kulturze danego kraju może motywować uczniów do nauki, w przypadku języków bardzo popularnych, wprowadzanie elementów kulturowych może nie mieć znaczenia w zwiększaniu motywacji ucznia.

3. Biografie są zawsze osadzone w kontekście społeczno-kulturowo-politycznym, a zatem dobrze obrazują, które czynniki z perspektywy czasu, stają się najważniejsze dla konkretnego nauczyciela. Miniona epoka wyróżniała nauczycieli języka rosyjskiego, zaś dekada po-transformacyjna wyraźnie preferowała nauczycieli języków zachodnich, spychając naukę języka rosyjskiego na daleki plan. Współcześni polscy nauczyciele (zwłaszcza języka francuskiego i niemieckiego) również borykają się z problemami bezrobocia czy koniecznością przekwalifikowania spowodowanymi niskim statusem nauczanych przez nich języków. Należy jednak pamiętać, że niechęć do nauki konkretnego JO w danym momencie historycznym ma często podłoże emocjonalne, a nie racjonalne.

4. Analizowanie biografii zawodowych byłych nauczycieli JO umożliwia poznanie indywidualnych doświadczeń konkretnych osób, jak również rekonstrukcję ogólnych poglądów, postaw, decyzji cechujących tę grupę zawodową. Dlatego biografia może służyć za ważną przestrzeń uczenia się przyszłych nauczycieli. Oprócz rozszerzenia wiedzy pedeutologicznej, poznanie biografii innych może wzmocnić kandydatów na nauczycieli w ich zawodowych wyborach, zmniejszyć stres i frustrację związaną z podjęciem zawodu pedagoga, jednym słowem, uczynić ich bardziej samoświadomymi i dojrzałymi. 
Biografia zawodowa jako źródło wiedzy - autobiograficzne refleksje...

5. Zastosowanie triady reaktywność-emotywność-sprawczość umożliwia badania biografii nauczycieli w czasie, a także porównanie stanów przeszłych z obecnymi. Można wykorzystać tę koncepcję w celu badania wskaźników reaktywności, emotywności i sprawczości kandydatów na nauczycieli JO, prognozując tym samym reakcje, emocje, czy wartości uznawane przez konkretne osoby, jak również ich zmienność w czasie.

Podsumowując rozważania, autorka żywi nadzieję, że niniejsze opracowanie zachęci do szerzej zakrojonych badań nad przebiegiem karier zawodowych emerytowanych nauczycieli JO, które do tej pory nie były przedmiotem pogłębionej refleksji.

\section{BIBLIOGRAFIA}

Biedroń, A. 2012. Cognitive-Affective Profile of Gifted Adult Foreign Language Learners. Słupsk: Akademia Pomorska.

Birch, B. M. 2009. The English Language Teacher in Global Civil Society. New York: Routledge.

Dörnyei, Z. 2009. „The L2 Motivational Self System” (w:) Motivation, Language Identity and the L2 Self (red. Z. Dörnyei i E. Ushioda). Bristol-Buffalo-Toronto: Multilingual Matters: 9-42.

Dubas, E. 2011. “Ja mam parę żyć - uczenie się z własnej biografii (w świetle analizy jednego wywiadu)" (w:) Uczenie się z (własnej) biografii (red. E. Dubas i W. Świtalski. Łódź: Wydawnictwo Uniwersytetu Łódzkiego: 197-213.

Gardner, R.C. i W.E. Lambert. 1972. Attitudes and Motivation in Second Language Learning. Rowley, MA: Newbury House.

Jaroszewska, A. 2013. Nauczanie języków obcych seniorów w Polsce. Kraków: Impuls.

Kwiatkowska, H. 2004. Tożsamość nauczycieli. Gdańsk: Gdańskie Wydawnictwo Psychologiczne.

Lalak, D. 2010. Życie jako biografia. Podejście biograficzne w perspektywie pedagogicznej. Warszawa: Wydawnictwo Akademickie „Żak”.

Ligus, R. 2009. Biograficzna tożsamość nauczycieli. Wrocław: Wydawnictwo Naukowe Dolnośląskiej Szkoły Wyższej.

Łatacz, E. 2011. „Osoba i jej rozwój - analiza w oparciu o poglądy Karola Wojtyły - propozycje 'klucza' do uczenia się z własnej biografii" (w:) Uczenie się z (własnej) biografii (red. E. Dubas i W. Świtalski). Łódź: Wydawnictwo Uniwersytetu Łódzkiego: 91-104.

Malewski, M. 2010. Od nauczania do uczenia się. O paradygmatycznej zmianie $w$ andragogice. Wrocław: Wydawnictwo Naukowe Dolnośląskiej Szkoły Wyższej.

Norton, B. 2013. Identity and Language Learning. Extending the Conversation. Bristol: Multilingual Matters.

Nowak-Łojewska, A. 2011. Od szkolnego przekazu do konstruowania znaczeń. Zielona Góra: Uniwersytet Zielonogórski.

Pavlenko, A. 2007. „Autobiographic narratives as data in applied linguistics”. Applied Linguistics 28(2): 163-188. 
Risager, K. 1998. „Language teaching and the process of European integration” (w:) Language Learning in Intercultural Perspective (red. M. Byram i M. Fleming). Cambridge: Cambridge University Press: 242-254.

Wejland, A.P. 2011. „Tożsamość i obcość w naukowym świecie humanistów” (w:) Biografie naukowe. Perspektywa transdyscyplinarna (red. M. Kafar). Łódź: Wydawnictwo Uniwersytetu Łódzkiego: 15-36.

Werbińska, D. 2004. Skuteczny nauczyciel języka obcego. Warszawa: Fraszka Edukacyjna.

Wojtyła, K. 1994. Osoba i czyn oraz inne studia antropologiczne. Lublin: KUL.

Wojtyła, K. 1999. Rozważania o istocie człowieka. Kraków: Wydawnictwo WAM.

Zawadzka, E. 2004. Nauczyciele języków obcych w dobie przemian. Kraków: Impuls. 